\title{
Identifikasi Mutasi Gen $\beta$ Globin Ekson 1 Pada Pembawa Thalassemia
}

\author{
NIKEN SATUTI NUR HANDAYANI ${ }^{1}$, ANDIKA TRIPRAMUDYA ONGGO² \\ ${ }^{1}$ Fakultas Biologi, Universitas Gadjah Mada \\ Jl. Teknika Selatan Sekip Utara Sleman Yogyakarta 55281 \\ email: niken_satuti@ugm.ac.id \\ ${ }^{2}$ Fakultas Biologi, Universitas Gadjah Mada \\ Jl. Teknika Selatan Sekip Utara Sleman Yogyakarta 55281 \\ email: tripramudyaandika@gmail.com
}

\begin{abstract}
Thalassemia is an autosomal recessive genetic mutation disorder with symptoms similliar to anemia that causes deficiency synthesis of the globin chains (hemoglobin component inside erythrocytes). Thalassemia is classified based on secondary protein structure abnormalities in $\alpha$ globin protein or $\beta$ globin protein. Based on data from Indonesian Thalassemia Foundation (YTI) in Indonesia, people with thalassemia, especialy $\beta$ thalassemia is constantly increasing 8 to $10 \%$ per year, so it is very impotant to have a strategy that reduce the increasing number in the population. Genetic examination on the individual is very effective to detect quickly the person with thalassemia trait carrier, to reduce the number of thalassemia carrier population. Identification of 1 st exon $\beta$ globin gene mutations with sequencing method is one of the way to know the specific mutation in thalassemia carriers. Identification results can be used as a reference for the rapid detection of thalassemia trait carrier. This study aims to determine the type of mutation and location of nucleotide mutations in 1st exon $\beta$ globin gene on carrier of thalassemia and the changes of amino acid translated by the mutant gene. The study was conducted by isolating the genome from the $\beta$ thalassemia carrier blood, amplifying and sequencing the 1 st exon $\beta$ globin gene. The location of point mutation analysis and the changes of amino acid, was analyzed using computational method by comparative alignment using normal $\beta$ globin gene as a comparison. The results of the research showed there is a point mutation in the $59^{\text {th }}$ nucleotide caused by transition ( $T$ to $C$ ) and $147^{\text {th }}$ nucleotide caused by transversion $(\mathrm{G}$ to $\mathrm{C})$. The mutation type found on this study was a silent mutation because there is no change in the translated amino acid.
\end{abstract}

Keywords: $\beta$ globin, exon 1, mutation, thalassemia

\section{PENDAHULUAN}

Thalassemia merupakan kelainan genetik akibat mutasi gen yang bersifat autosomal resesif yang disebabkan kekurangan sintesis rantai globin pembentuk hemoglobin darah dengan gejala mirip anemia (Galanello \& Origa, 2010). Penyandang thalassemia memiliki hemoglobin $(\mathrm{Hb})$ dalam sel darah merah (eritrosit) yang tidak dapat mengikat oksigen dengan baik. Dengan kondisi yang demikian maka penyandang thalassemia sering merasa lemas karena kekurangan oksigen terlarut dalam darah.

Thalassemia diklasifikasikan berdasar kelainan molekul sekunder protein $\alpha$ globin atau protein $\beta$ globin. Thalassemia $\alpha$ memiliki kelainan pada protein $\alpha$ globin, sedangkan thalassemia $\beta$, pada protein $\beta$ globin (Guyton \& Hall, 2010). Di Indonesia, penyandang thalassemia, menurut Ketua Umum Yayasan Talasemia Indonesia (YTI), Rinie Amaludin, terus meningkat 8 hingga $10 \%$ per tahun, sehingga diperlukan penelitian dan strategi untuk menekan jumlah penyandang dalam populasi (Ansari \& Shamsi, 2010).

Pemeriksaan terhadap pembawa thalassemia sangat efektif untuk menekan jumlah populasi penyandang, melalui pemeriksaan hematologis, yang dilanjutkan dengan deteksi letak mutasi. Thalassemia $\beta$ terjadi karena mutasi gen HBB pada kromosom nomor 11 sehingga identifikasi mutasi gen $\beta$ globin ekson 1 pada gen HBB kromosom nomor 11, dengan metode 
sekuensing merupakan cara efektif mengetahui mutasi spesifik pada pembawa thalassemia yang dapat digunakan sebagai acuan untuk deteksi cepat pembawa sifat thalassemia.

Penelitian ini untuk mempelajari dan mengetahui jenis mutasi apakah yang terjadi di gen $\beta$ globin ekson 1 pada pembawa thalassemia; serta mempelajari dan mengetahui letak mutasi nukleotida yang terjadi pada gen $\beta$ globin ekson 1 dan perubahan asam amino yang disandi pada pembawa thalassemia.

\section{METODE}

Tabel 1. Rekapitulasi hasil uji hematologis dan uji PCR-SSCP sampel darah

\begin{tabular}{|c|c|c|c|c|c|c|c|c|}
\hline \multirow{2}{*}{$\begin{array}{c}\text { Kode Subjek } \\
\text { Penelitian }\end{array}$} & \multicolumn{4}{|c|}{ Hasil Uji Hematologis } & \multicolumn{4}{|c|}{ Hasil Uji PCR-SSCP } \\
\hline & $\mathrm{CBC}$ & $\mathrm{MC}$ & GDT & HPLC & Region I & Region II & Region III & Region IV \\
\hline P4 & + & + & + & + & + & - & - & - \\
\hline P13 & + & + & + & + & + & - & - & - \\
\hline P14 & + & + & + & + & + & - & - & - \\
\hline P15 & + & + & + & + & + & + & - & - \\
\hline P16 & + & + & + & + & + & - & - & + \\
\hline P17 & + & + & + & + & + & + & - & + \\
\hline P18 & + & + & + & + & + & - & - & + \\
\hline P19 & + & + & + & + & + & - & - & - \\
\hline P20 & + & + & + & + & + & - & - & + \\
\hline P21 & + & + & + & + & + & - & - & - \\
\hline
\end{tabular}

Keterangan: CBC: Cell Blood Count, MC: Mean Corpuscular, GDT: Gambaran Darah Tepi, HPLC: High Performance Liquid Chromatography, P4-P21: Subjek penelitian terduga pembawa sifat thalassemia $\beta$, tanda plus $(+)$ menunjukkan adanya kondisi abnormalitas pada masing-masing parameter, tanda minus (-) menunjukkan kondisi normal pada masing-masing parameter (Priyambodo, 2014).

Tabel 2. Sekuen primer untuk amplifikasi gen $\beta$ globin ekson 1 (Gupta \& Argawal, 2003)

\begin{tabular}{lll} 
Primer & Sekuen & Ukuran amplikon \\
\hline Primer F & 5' CCAAGGACAGGTACGGCTGTCATC 3' & 322bp \\
Primer R & 5' CTATTGGTCTCCTAAACCTGTCTTG 3, &
\end{tabular}

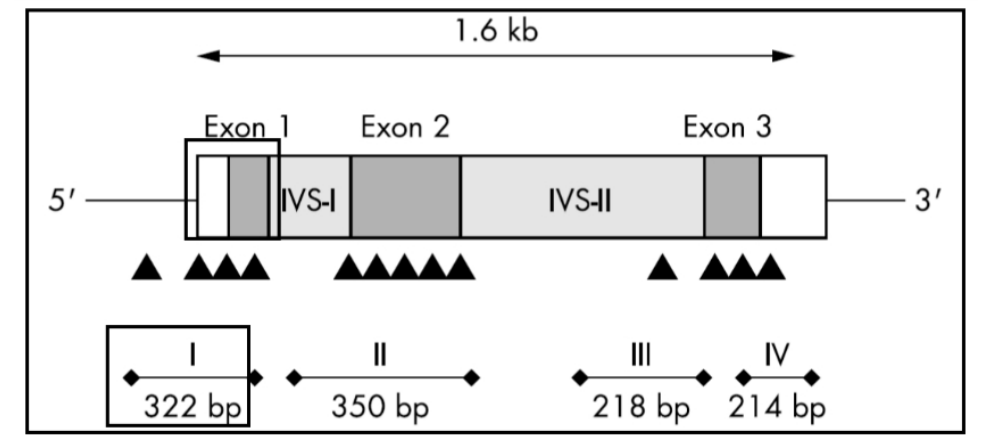

Gambar 1. Representasi gen $\beta$-globin dan lokasi primer, daerah amplifikasi dan ukuran amplikon (bp). IVS, intervening sequence (intron)

Bahan yang digunakan dalam penelitian adalah 10 sampel darah yang berasal dari subyek penelitian sebelumnya oleh Priyambodo pada 2014, yang sudah dideteksi memiliki mutasi gen $\beta$ globin ekson 1, dengan kondisi hematologis dan hasil PCR-SSCP ditunjukkan pada Tabel 1, DNA Ladder
Vivantis 100 bp, PCR master mix KAPA 2G ${ }^{\mathrm{TM}}$ Fast Ready Mix, ethidium bromide (EtBr), gel agarosa Biotechnology Grade, akuades, buffer Tris-Borat EDTA (TBE) 10x, EDTA, pewarna Good View dan primer spesifik (Tabel 2) untuk amplifikasi segmen gen $\beta$, sehingga amplikon sesuai dengan target pada Gambar 1, 
mencangkup seluruh ekson 1. Penelitian ini dimulai dengan mengisolasi genom DNA dari whole blood pembawa thalassemia $\beta$ sampel penelitian pendahulu yang dideteksi memiliki mutasi di region 1 (Priyambodo, 2014). Isolasi genom dilakukan dengan kit produk GeneAid. DNA Genom yang didapat diperiksa kualitasnya dengan elektroforesis di agarose gel $1 \%$. Gen $\beta$ globin ekson 1 diamplifikasi dengan Thermocyler menggunakan primer (Tabel 2). Amplifikasi menggunakan $25 \mu 1$ reaction mixture dengan komposisi $12,5 \mu \mathrm{l}$ PCR Mix KAPA 2G ${ }^{\mathrm{TM}}$ Fast Ready Mix, $3 \mu 1$ DNA template, $1,25 \mu 1$ forward primer (10 pmol), $1,25 \mu 1$ reverse primer $(10$ pmol $) \& 7$ $\mu \mathrm{l} \mathrm{ddH}_{2} \mathrm{O}$. Suhu proses predenaturasi amplifikasi $95^{\circ} \mathrm{C}$ selama 3 menit. Denaturasi $95^{\circ} \mathrm{C}$ selama 15 detik, annealing $54{ }^{\circ} \mathrm{C}$ selama 30 detik, elongasi $72{ }^{\circ} \mathrm{C}$ selama 45 detik, dari denaturasi hingga elongasi diulangi sebanyak 35 cycle. Pasca elongasi $72{ }^{\circ} \mathrm{C}$ selama 5 menit $\&$ pendinginan $4{ }^{\circ} \mathrm{C}$ selama 5 menit.

Amplikon yang didapat, diperiksa kualitasnya dengan elektroforesis di agarose gel $1 \%$, kemudian disekuensing oleh perusahaan 1stBase dengan alat sequencer AB13730XL. Hasil sekuensing dibandingkan dengan database gen normal $\beta$ globin (www.ncbi.nlm.nih.gov/genbank/, dengan Reference Sequence Accession: NC_000011.10), sehingga dapat diketahui mutasinya. Software yang digunakan: Chromas untuk mengecek hasil sekuensing \& software MEGA untuk alignment serta melihat hasil translasi digunakan.

\section{HASIL}

Hasil sekuensing ekson 1 dari sampel dibandingkan dengan database gen $\beta$ globin dari NCBI dengan cara disejajarkan menggunakan software MEGA 6.0. Tabel 3 menunjukkan hasil alignment urutan nukleotida ke 1 hingga ke 150 gen normal penyandi protein $\beta$ globin dari database gen NCBI dengan sampel yang diteliti. Gen $\beta$ globin ekson 1 adalah urutan nukleotida ke 1 hingga ke 142 sehingga urutan nukleotida ke 143 hingga ke 150 merupakan intron. Hasil alignment pada urutan nukleotida ke 1 hingga ke 50 menunjukkan bahwa tidak ada perbedaan nukleotida sama sekali, sehingga disimpulkan bahwa pada urutan nukleotida ke 1 hingga ke 50 tidak ada mutasi yang terjadi. Urutan nukleotida ke 1 hingga ke 50 merupakan ekson 1 gen $\beta$ globin tetapi bukan merupakan CDS (Coding Sequences), sehingga urutan nukleotida ke 1 hingga ke 50 tidak ditranslasikan menjadi asam amino untuk gen $\beta$ globin.

Alignment urutan nukleotida ke 51 hingga ke 100 menunjukkan bahwa ada perbedaan nukleotida gen pada 7 sampel (sampel 14, 16, 17, 18, 19, 20 dan 21), yaitu pada site ke 59 . Mutasi yang terjadi adalah timin menjadi sitosin. Perbedaan nukleotida (tabel 3) ditandai dengan format blok berwarna abu-abu dan huruf Italic, menunjukkan adanya mutasi di ekson 1 gen $\beta$ globin. Urutan nukleotida ke 51 hingga ke 100 merupakan CDS, sehingga ikut ditranslasikan menjadi asam amino untuk gen $\beta$ globin.

Alignment pada urutan nukleotida ke 101 hingga ke 150 menunjukkan bahwa terdapat perubahan nukleotida guanin menjadi sitosin pada urutan nukleotida ke 147 pada sampel 14, 16, 17, 18, 20 dan 21. Bagian dari ekson utama dari nukleotida ke 101 hingga ke 142 tidak ada mutasi yang terjadi sama sekali. Urutan nukleotida ke 101 hingga ke 142 merupakan bagian CDS (Coding Sequences), sehingga urutan nukleotida ke 101 hingga ke 142 ikut ditranslasikan menjadi asam amino untuk gen $\beta$ globin, sedangkan nukleotida 143 hingga ke 150 tidak ditranslasikan.

Tabel 4 menunjukkan alignment translasi kodon gen menjadi rantai asam amino. Bagian paling atas (nomor 1) merupakan urutan asam amino normal yang didapat dari NCBI. Hasil menunjukkan urutan asam amino protein hasil translasi kodon sampel tidak ada perbedaan dengan urutan asam amino normal. Mutasi titik pada penelitian ini tidak menunjukkan/ mengakibatkan perubahan asam amino sama sekali karena satu asam amino dapat disandi lebih dari satu macam kodon yang lain, artinya mutasi gen ini adalah mutasi diam. 
Tabel 3. Alignment sekuens Nukleotida urutan ke 1 hingga ke 150 dari gen normal $\beta$ globin ekson 1dari database NCBI dan sekuens gen $\beta$ globin ekson 1 dari sampel

\begin{tabular}{|c|c|}
\hline $\begin{array}{l}\text { Subjek } \\
\text { Penelitan }\end{array}$ & Urutan Nukleotida ke 1 hingga ke 50 \\
\hline &  \\
\hline $\begin{array}{l}\text { Data } \\
\text { NCBI }\end{array}$ & ACATTTGCTTCTGACACAACTGTGTTCACTAGCAACCTCAAACAGACACC \\
\hline Sampel 4 & ACATTTGCTTCTGACACAACTGTGTTCACTAGCAACCTCAAACAGACACC \\
\hline $\begin{array}{l}\text { Sampel } \\
14\end{array}$ & ACATTTGCTTCTGACACAACTGTGTTCACTAGCAACCTCAAACAGACACC \\
\hline $\begin{array}{l}\text { Sampel } \\
16\end{array}$ & ACATTTGCTTCTGACACAACTGTGTTCACTAGCAACCTCAAACAGACACC \\
\hline $\begin{array}{l}\text { Sampel } \\
17\end{array}$ & ACATTTGCTTCTGACACAACTGTGTTCACTAGCAACCTCAAACAGACACC \\
\hline $\begin{array}{l}\text { Sampel } \\
18\end{array}$ & ACATTTGCTTCTGACACAACTGTGTTCACTAGCAACCTCAAACAGACACC \\
\hline $\begin{array}{l}\text { Sampel } \\
19\end{array}$ & ACATTTGCTTCTGACACAACTGTGTTCACTAGCAACCTCAAACAGACACC \\
\hline $\begin{array}{l}\text { Sampel } \\
20\end{array}$ & ACATTTGCTTCTGACACAACTGTGTTCACTAGCAACCTCAAACAGACACC \\
\hline $\begin{array}{l}\text { Sampel } \\
21\end{array}$ & ACATTTGCTTCTGACACAACTGTGTTCACTAGCAACCTCAAACAGACACC \\
\hline $\begin{array}{l}\text { Subjek } \\
\text { Penelitan }\end{array}$ & Urutan Nukleotida ke 51 hingga ke 100 \\
\hline & $\ldots 100$ \\
\hline $\begin{array}{l}\text { Data } \\
\text { NCBI }\end{array}$ & ATGGTGCATCTGACTCCTGAGGAGAAGTCTGCCGTTACTGCCCTGTGGGG \\
\hline Sampel 4 & ATGGTGCATCTGACTCCTGAGGAGAAGTCTGCCGTTACTGCCCTGTGGGG \\
\hline $\begin{array}{l}\text { Sampel } \\
14\end{array}$ & ATGGTGCACCTGACTCCTGAGGAGAAGTCTGCCGTTACTGCCCTGTGGGG \\
\hline $\begin{array}{l}\text { Sampel } \\
16\end{array}$ & ATGGTGCACCTGACTCCTGAGGAGAAGTCTGCCGTTACTGCCCTGTGGGG \\
\hline $\begin{array}{l}\text { Sampel } \\
17\end{array}$ & ATGGTGCACCTGACTCCTGAGGAGAAGTCTGCCGTTACTGCCCTGTGGGG \\
\hline $\begin{array}{l}\text { Sampel } \\
18\end{array}$ & ATGGTGCACCTGACTCCTGAGGAGAAGTCTGCCGTTACTGCCCTGTGGGG \\
\hline $\begin{array}{l}\text { Sampel } \\
19\end{array}$ & ATGGTGCACCTGACTCCTGAGGAGAAGTCTGCCGTTACTGCCCTGTGGGG \\
\hline $\begin{array}{l}\text { Sampel } \\
20\end{array}$ & ATGGTGCACCTGACTCCTGAGGAGAAGTCTGCCGTTACTGCCCTGTGGGG \\
\hline $\begin{array}{l}\text { Sampel } \\
21\end{array}$ & ATGGTGCACCTGACTCCTGAGGAGAAGTCTGCCGTTACTGCCCTGTGGGG \\
\hline
\end{tabular}

Subjek

Urutan Nukleotida ke 101 hingga ke 150

Penelitan

$101 \ldots$ $\ldots 150$

Data CAAGGTGAACGTGGATGAAGTTGGTGGTGAGGCCCTGGGCAGGTTGGTAT

NCBI

Sampel 4 CAAGGTGAACGTGGATGAAGTTGGTGGTGAGGCCCTGGGCAGGTTGGTAT

Sampel CAAGGTGAACGTGGATGAAGTTGGTGGTGAGGCCCTGGGCAGGTTGCTAT

14

Sampel CAAGGTGAACGTGGATGAAGTTGGTGGTGAGGCCCTGGGCAGGTTGCTAT 16 


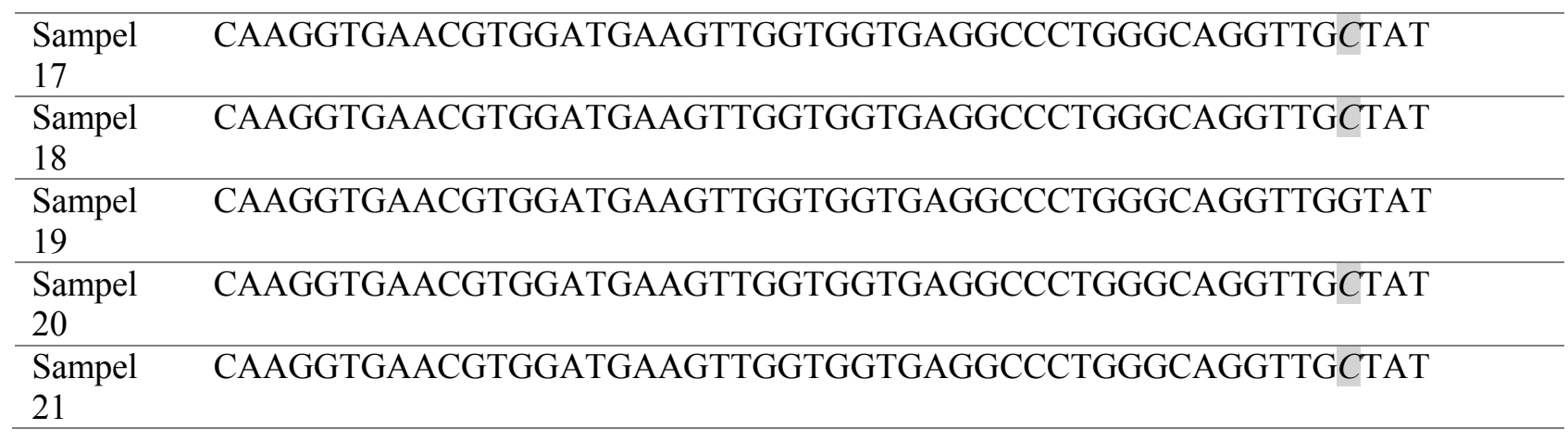

Tabel 4. Alignment urutan asam amino hasil translasi gen normal dari database NCBI dan urutan asam amino hasil translasi gen $\beta$ ekson 1 globin sampel

\begin{tabular}{lll} 
No. & Subjek Penelitan & \multicolumn{1}{c}{ Urutan Asam Amino ke 1 hingga ke 30} \\
\hline 1. & $\begin{array}{l}\text { Hasil translasi gen normal } \beta \\
\text { globin ekson 1 dari NCBI }\end{array}$ & MVHLTPEEKSAVTALWGKVNVDEVGGEALG \\
\hline 2. & Sampel 4 & MVHLTPEEKSAVTALWGKVNVDEVGGEALG \\
\hline 3. & Sampel 14 & MVHLTPEEKSAVTALWGKVNVDEVGGEALG \\
\hline 4. & Sampel 16 & MVHLTPEEKSAVTALWGKVNVDEVGGEALG \\
\hline 5. & Sampel 17 & MVHLTPEEKSAVTALWGKVNVDEVGGEALG \\
\hline 6. & Sampel 18 & MVHLTPEEKSAVTALWGKVNVDEVGGEALG \\
\hline 7. & Sampel 19 & MVHLTPEEKSAVTALWGKVNVDEVGGEALG \\
\hline 8. & Sampel 20 & MVHLTPEEKSAVTALWGKVNVDEVGGEALG \\
\hline 9. & Sampel 21 & MVHLTPEEKSAVTALWGKVNVDEVGGEALG
\end{tabular}

\section{PEMBAHASAN}

Penelitian menggunakan sampel yang telah diuji hematologis dan uji PCR-SSCP oleh Priyambodo pada 2014 (Tabel 1). Pembawa sifat thalassemia dapat dilihat dengan parameter hematologis meliputi pengecekkan MCV (Mean Corpuscular Volume), $\mathrm{MCH}$ (Mean Corpuscular Hemoglobin), GDT (Gambaran Darah Tepi) dan HPLC (HighPerformance Liquid Chromatography). (Hoffbrand et al., 2006).

Pada Tabel 1 diketahui bahwa seluruh sampel yang digunakan dalam penelitian ini memiliki mutasi di gen $\beta$ globin region 1 dan juga memiliki kondisi hematologis yang positif pembawa sifat thalassemia. Penelitian ini fokus mengidentifikasi mutasi spesifik nukleotida pada gen $\beta$ globin ekson 1 yang tercangkup dalam region 1. Gen yang menyandi protein $\beta$ globin tersusun dari 3 ekson pokok dalam 3 region yang berbeda dan dipisahkan oleh intron. Pada penelitian dilakukan alignment yaitu penjajaran basabasa nukleotida yg telah terbaca dari hasil sekuensing dengan gen $\beta$ globin normal dari database gen NCBI. Saat dibandingkan dengan gen normal, jika terdapat mutasi maka akan terlihat dengan mudah perbedaan nukleotida yang terjadi.

Sekuens yang diambil dari database NCBI gen normal Human B globin kromosom 11 (Gambar 2), menunjukkan bahwa nukleotida nomor 1 hingga ke 142 akan ditranslasikan menjadi mRNA untuk ekson 1 dari $\beta$ globin. Nukleotida ke 273 hingga ke 495 akan ditranslasikan menjadi mRNA untuk ekson 2 dari $\beta$ globin, sedangkan nukleotida 1346 hingga nukleotida ke 1606 akan ditranslasikan menjadi mRNA untuk ekson 3. Di luar dari daerah tersebut adalah intron. Secara umum intron biasanya mempunyai repeat sequences untuk melindungi ekson dari mutasi. Database tersebut terdapat Coding Sequences (CDS) yang identik untuk mengkode kodon protein, yaitu nukleotida ke 51 hingga ke 142 untuk ekson 1 (pada bagian yang diblok dengan warna abu-abu), nukleotida 273 hingga ke 495 untuk translasi ekson 2 dan nukleotida ke 1346 hingga ke 1474 untuk ekson 3. Penelitian ini difokuskan pada ekson 1 sehingga hanya data sekuens dari nukleotida ekson 1 yang digunakan. 


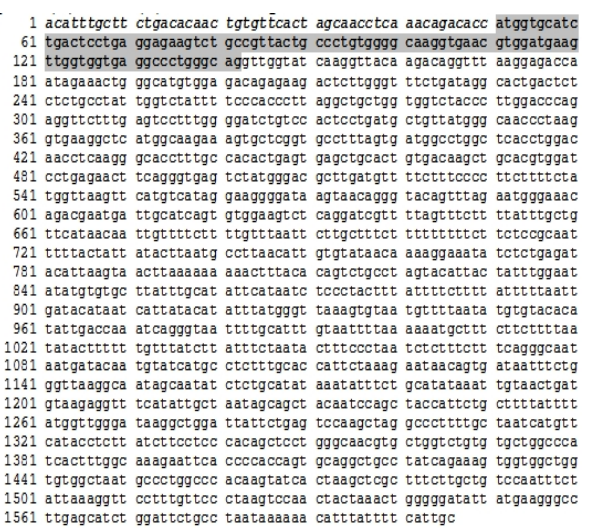

Gambar 2. Sekuens gen normal Human B globin kromosom 11 dari database NCBI

Alignment keseluruhan dari urutan nukleotida ke 1 hingga ke 150 (Tabel 3) menunjukkan bahwa terdapat perbedaan nukleotida yang terletak pada site ke 59 dan ke 147. Perbedaan nukleotida tersebut menunjukkan adanya mutasi di ekson 1 gen $\beta$ globin. Terdapat 7 sampel (sampel 14, 16, 17, $18,19,20$ dan 21) di penelitian ini yang memiliki mutasi pada intron gen $\beta$ globin di site ke 59, sedangkan mutasi pada site ke 147 hanya terjadi pada 6 sampel (sampel 14, 16, 17, 18, 20 dan 21). Mutasi pada nukleotida pada site ke 59 sering ditemukan di wilayah Thailand, yang merupakan satu wilayah Asia Tenggara bersama Indonesia (Cao \& Galanello, 2010).

Mutasi yang terjadi \& teramati dipenelitian ini adalah pada nukleotida ke 59 $\&$ nukleotida ke 147 gen $\beta$ globin ekson 1 . Mutasi ini sangat spesifik berupa perubahan satu basa nukleotida. Mutasi bertipe transisi terjadi pada nukleotida ke 59 dengan perubahan $\mathrm{T}$ (timin) berubah menjadi $\mathrm{C}$ (sitosin). Mutasi di nukleotida ke 147 berupa perubahan nukleotida dari $\mathrm{G}$ (guanin) berubah menjadi C (sitosin) di bagian intron. Mutasi pada site nukleotida ini berupa transversi, yaitu nukleotida purin berubah menjadi nukleotida pirimidin atau sebaliknya. Mutasi titik pada penelitian ini tidak menunjukkan/ mengakibatkan perubahan asam amino sama sekali (Tabel 4), artinya mutasi gen ini adalah mutasi diam (silent mutation). Satu mutasi yang lainnya terjadi di intron. Sebelum gen ditranslasikan intron dipotong, dipisahkan dari ekson. Perubahan pada intron pada beberapa kasus dapat mengakibatkan kesalahan pada saat splicing, yang mengakibatkan kesalahan penyandian asam amino (Cao \& Galanello, 2010), sehingga diduga bahwa pada penelitian ini walaupun secara in silico pada hasil sandi asam amino tidak ada perubahan, namun secara in vivo saat splicing dapat terjadi kesalahan splicing. Berikut ini adalah hasil translasi gen $\beta$ globin ekson 1 normal maupun mutan di dalam penelitian: "MVHLTPEEKSAVTALWGKVNVDEVGG EALG". Hasil translasi yang diperoleh dengan analisis menggunakan software MEGA 6.0 adalah bahwa alel mutan tidak menyebabkan perubahan asam amino yang dikode, maka analisis struktur tiga dimensi tidak dilakukan.

Penelitian ini adalah rintisan pertama identifikasi mutasi gen $\beta$ globin ekson 1 di Indonesia sehingga penelitian lanjut untuk mengetahui jenis mutasi di luar ekson 1 perlu dilakukan, selain itu perlu diadakan penelitian lebih lanjut secara in vivo pada saat splicing sehingga diketahui apakah mutasi pada intron gen $\beta$ globin ekson 1 mengakibatkan kesalahan splicing.

\section{KESIMPULAN}

Pada penelitian ini terjadi mutasi berjenis silent mutation. Perubahan nukleotida yang terjadi di gen $\beta$ globin ekson 1 adalah di nukleotida ke 59 secara transisi ( $\mathrm{T}$ berubah menjadi C) serta nukleotida ke 147 secara transversi ( $\mathrm{G}$ berubah menjadi $\mathrm{C}$ ).

\section{UCAPAN TERIMAKASIH}

Ucapan terima kasih kepada: Dr. Niken Satuti Nur Handayani, M.Sc., Dra. Rarastoeti Pratiwi, M.Sc., Ph.D \& Dr. biol. hom. Nastiti Wijayanti, M.Si., Kedua orangtua \& adik saya, Tanoto Foundation yang membantu pendanaan penelitian \& publikasi, YTI \& POPTI yang menyediakan sampel penelitan dan membantu penelitian ini, serta seluruh pihak yang tidak dapat saya sebutkan satu persatu, yang telah membantu pelaksanaan penyusunan naskah ini.

\section{DAFTAR PUSTAKA}

Ansari SH and Shamsi TS. 2010. Thalassemia Prevention Programme. Karachi: National 
Institute of Blood Disease and Bone Marrow Transplantation.

Cao A and Galanello R. 2010. B-thalassemia. GeneTest Review. Genetics in Medicine. vol 12 (2): 1.

Galanello R and Origa R. 2010. B Thalassemia. Orphanet Journal of Rare Diseases. vol 5 (1): 1-15.

Hoffbrand AV, Pettit JE, Moss PAH. 2006. Essential Haematology Fifth Edition. Massachusetts: Blackwell Science, Inc.
Huang SZ, Zhou XD, Zhu H, Ren ZR, Zeng YT. 1989. Detection of $\beta$-thalassemia Mutations in Chinese Using Amplified DNA from Dried Blood Specimens. Hum. Genet. vol 84: 129-131.

Priyambodo. 2014. Deteksi Molekular Pembawa Sifat $\beta$-Thalassemia di Daerah Istimewa Yogyakarta [Tesis]. Yogyakarta: Program Pascasarjana Fakultas Biologi Universitas Gadjah Mada. 